\title{
Deep ice-core drilling at Dome Fuji and glaciological studies in east Dronning Maud Land, Antarctica
}

\author{
Dome-F Deep Coring Group* \\ National Institute of Polar Research, 9-10, Kaga 1-chome, Itabashi-ku, Tokyo 173-8515, Japan
}

\begin{abstract}
The Dome Fuji Project is a comprehensive study of present and past glaciological/climatological features of the Antarctic ice sheet in east Dronning Maud Land. Field observations on a $1000 \mathrm{~km}$ traverse route from the coast to Dome Fuji show changes in various glaciological parameters with surface elevation and distance from the coast. Deep ice-core drilling at Dome Fuji was started in August 1995 and reached a depth of $2503.52 \mathrm{~m}$ in December 1996. In situ core analyses revealed 25 visible tephra layers and a number of distinct cloudy bands in the ice.
\end{abstract}

\section{BACKGROUND OF THE PROJECT}

Japanese Antarctic Research Expeditions (JAREs) have collected glaciological, climatological and geochemical data on the ice sheet in east Dronning Maud Land since 1968. As part of the International Geosphere-Biosphere Programme and the International Trans-Antarctic Scientific Expedition, the Dome Fuji Project (DFP) was designed as a comprehensive study of past and present glaciological/ climatological features of the Antarctic ice sheet in east Dronning Maud Land.

The principal parts of the project are the glaciological traverse from the ice-sheet margin to the top of Dome Fuji and the deep ice-coring at Dome Fuji station. The project was carried out between 1991 and 1996.

\section{TRAVERSE STUDY}

The oversnow traverse party of the JARE conducted glaciological and climatological observations, and in 1985 fixed the location of the second highest dome in Antarctica (Ageta and others, 1989). In 1991 and 1992 the DFP extended the study area from the coastal area to Dome Fuji, which is the summit of the Shirase and Ragnhild drainage basins (Kamiyama and others, 1994; Fujii and others, 1995). Glaciological data including surface elevation, ice thickness, surface ice velocity, snow accumulation, snow temperaturedepth profiles, stratigraphic and density profiles and snow surface features were collected along the traverse routes.

\footnotetext{
${ }^{*}$ Y. Ageta, N. Azuma, Y. Fujii, K. Fujino, S. Fujita, T. Furukawa, T. Hondoh, T. Kameda, K. Kamiyama, K. Katagiri, K. Kawada, T. Kawamura, S. Kobayashi, S. Mae, H. Maeno. T. Miyahara, H Motoyama, Y. Nakayama, R. Naruse, F. Nishio, K. Saitoh, T. Saitoh, K. Shimbori, T. Shiraiwa, H. Shoji, A. Takahashi, S. Takahashi, Y. Tanaka, $\mathrm{K}$. Yokoyama and $\mathrm{O}$. Watanabe (principal investigator).
}

\subsection{Regional characteristics}

Figure 1 shows a cross-section of the ice sheet (surface and bedrock elevation) and the distribution of snow accumulation (October 1991-December 1995) along the traverse route from the coast to Dome Fuji.

Furukawa and others (1996) showed that the traverse route can be divided into three sections on the basis of the characteristics of snow surface features: a coastal region, characterised by a high frequency of small sastrugi and low frequency of dunes; a katabatic-wind region characterised by the coexistence of small and large sastrugi, dunes and a glazed surface; and an inland region characterised by low frequencies of small sastrugi and dunes. These regional characteristics of snow surface features are due to deposition-erosion processes influenced by both the surface and bedrock topography of the ice sheet.

\subsection{Ice-flow velocity}

Ice-flow velocities at glaciological survey points along the traverse routes are shown in Figure 2. Data were obtained by chain survey, by satellite Doppler positioning and by differential global positioning system (GPS) (Naruse, 1978; Nishio and others, 1989; Motoyama and others, 1995a). Naruse (1978) and Nishio and others (1989) showed that east Dronning Maud Land can be divided into five drainage basins: the Soya, the Shirase, the Harald, the Ragnhild and the Asuka. Measurement of horizontal and vertical flow velocity, strain rate, inclination of the ice surface, accumulation rate and densification of snow was used to show that the ice sheet in the Shirase drainage basin at elevations below about $2800 \mathrm{~m}$ is thinning.

\subsection{Surface and bedrock topography of Dome Fuji}

The surface topography of the dome (see Fig. 3) is very smooth and flat. The surface elevation at six radial points $30 \mathrm{~km}$ from the summit is only 7-30 m (mean $20 \mathrm{~m}$ ) lower than the summit, and the mean surface slope within a radius of $30 \mathrm{~km}$ is estimated at $1 / 1500$. 


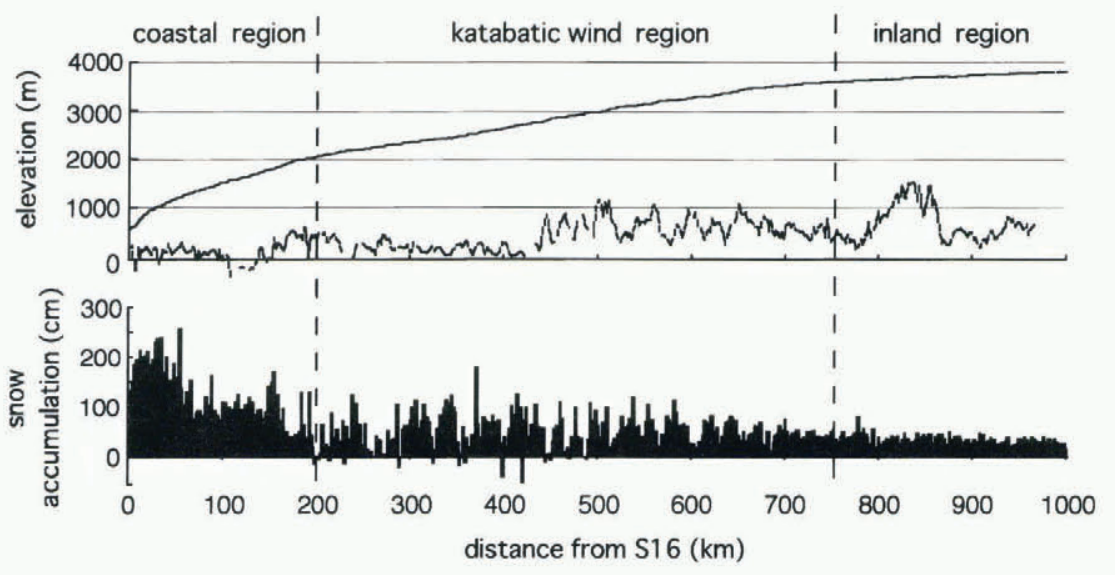

Fig. 1. Surface and bedrock profiles of the ice sheet and the distribution of net snow accumulation from October 1991 to December 1995 along the traverse route from the coast to Dome Fuji.

A topographical map, based on radio-echo sounding data collected in 1992-93 (Maeno and others, 1994) from the bedrock around Dome Fuji is shown in Figure 3.

The location of Dome Fuji station was decided on the basis of both surface and bedrock topography. The station is situated above relatively flat bedrock with an elevation of about $800 \mathrm{~m}$. The bedrock topography around the dome shows what appears to be a saddle point with bedrock hills more than $1000 \mathrm{~m}$ a.s.l. to the southeast and the northwest, and bedrock elevation below $600 \mathrm{~m}$ to the northeast and southwest.

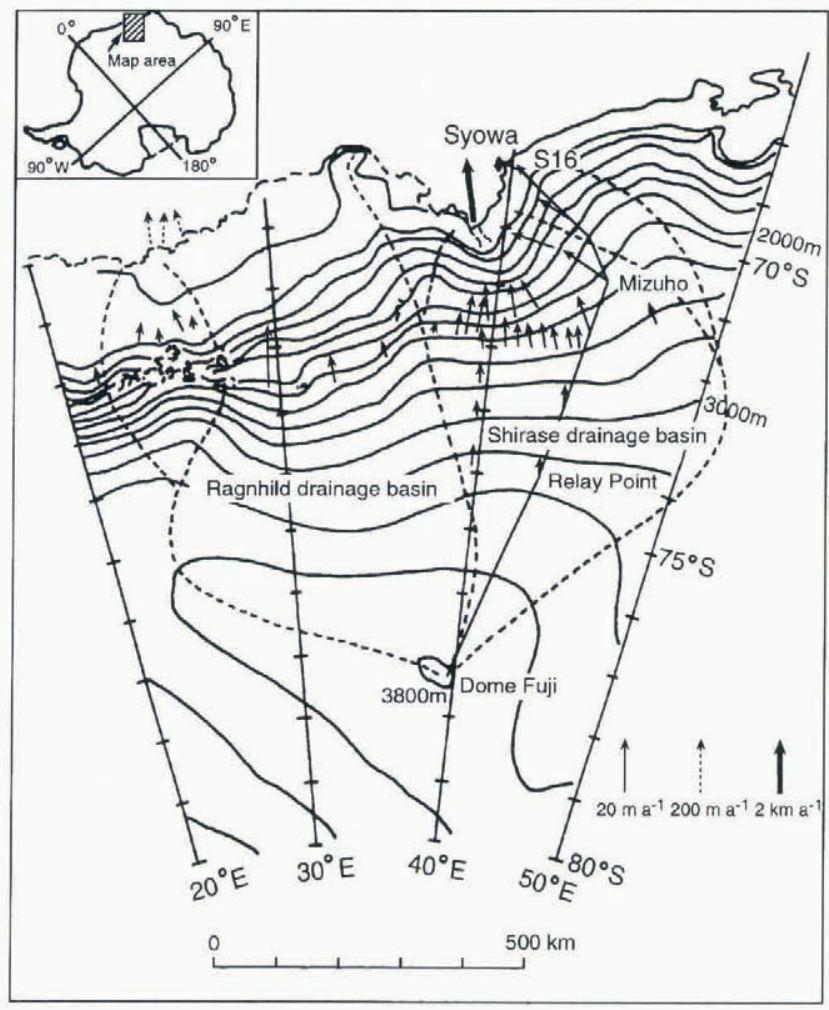

Fig. 2. Horizontal ice-flow vectors $\left(\mathrm{ma}^{-1}\right)$ obtained from satellite Doppler positioning (Nishio and others, 1989), from the triangulation chain along latitude $72^{\circ} S$ (Naruse, 1978) and from differential GPS (Motoyama and others, 1995a). Drainage-basin ice divides are shown by broken lines (Nishio and Ageta, 1997).

\subsection{Drilling-site}

Drilling-site parameters were investigated by surface observations, snow-pit measurements and analysis of $10 \mathrm{~m}$ cores (Ageta and others, 1989). Measured parameters are:

(1) Location: $77^{\circ} 19^{\prime} 01^{\prime \prime} \mathrm{S}, 39^{\circ} 42^{\prime} 12^{\prime \prime} \mathrm{E}$

(2) Altitude: $3810 \mathrm{~m}$ a.s.l.

(3) Ice thickness (estimated from radio-echo sounding): $3090 \mathrm{~m}$

(4) $10 \mathrm{~m}$ snow temperature: $-58.0^{\circ} \mathrm{C}$
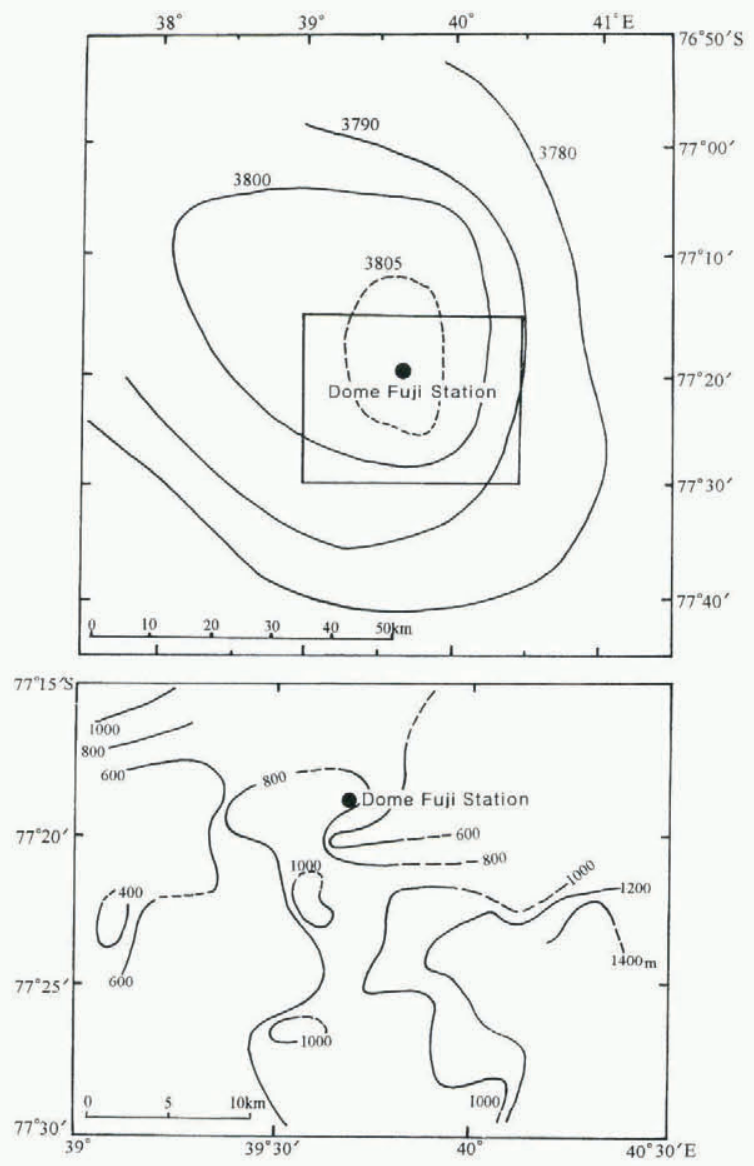

Fig. 3. Surface topography of Dome Fuji (above) and bedrock topography (below). 
(5) Mean annual net accumulation (measured 1966-85): $32 \mathrm{~mm}$ w.e.

\section{DEEP ICE-CORING AT DOME FUJI STATION}

We developed a deep ice-core drilling system after field experiments in Antarctica (in 1988 and 1989), at Dome GRIP, Greenland (in 1991 and 1992), and at Rikubetsu, Japan (in 1992, 1993 and 1994) (Tanaka and others, 1994). In 1993 a pilot hole was drilled to a depth of $112 \mathrm{~m}$ and borehole casing was fitted. Dome Fuji station was constructed in 1994 and deep ice-core drilling started in 1995. The drilling reached a depth of $2503 \mathrm{~m}$ in 1996.

\subsection{Casing}

The $135 \mathrm{~mm}$ diameter pilot borehole was drilled to a depth of $112 \mathrm{~m}$ and was reamed to $250 \mathrm{~mm}$ diameter to fit fibreglass-reinforced casing (Johnsen and others, 1994; Morgan and others, 1994) in 1993 (Motoyama and others, 1995b). The casing was fitted to a depth of $86 \mathrm{~m}$. Prior to deep icecoring in 1995, the casing was sealed at the bottom by refrozen wet snow to prevent the drill from catching against the bottom end of the casing when it was pulled up.

\subsection{Borehole liquid}

The borehole liquid was carefully chosen from the viewpoints of viscosity and density at temperatures as low as $-60^{\circ} \mathrm{C}$; effects on ice-core quality, drill and human health; environment; and flammability or volatility (Fujita and others, 1994). Eventually, n-butyl acetate was chosen which has low viscosity and appropriate density for the temperature at Dome Fuji.

\subsection{Drill system}

Table 1 shows the fundamental specifications. The drill was designed to be (i) light, (ii) easy to operate and (iii) safe under conditions at Dome Fuji (Tanaka and others, 1994).

The drill is of the double tube type. It consists of an outer tube and an inner barrel (or core barrel) $2.25 \mathrm{~m}$ long fitted with three cutters. Spirals are attached to the outside of the

Table 1. Specification of the deep ice-core drilling system used at Dome Fuji

Item

Specification

1. Drill

Outer diameter $122 \mathrm{~mm}$; length $8.54 \mathrm{~m}$; weight $200 \mathrm{~kg}$; core diameter $94 \mathrm{~mm}$; max. core length $2.24 \mathrm{~m}$; hole diameter $135 \mathrm{~mm}$ (nominal); drill motor 600 W d.c. brushless

2. Winch Motor $11 \mathrm{~kW}$; $\max$. load $3.4 \mathrm{t}$

3. Cable Length $3500 \mathrm{~m}$; steel-armoured, seven conductors; outer diameter $7.72 \mathrm{~mm}$; breaking strength $37.4 \mathrm{kN}$

4. Tower

Length $10.5 \mathrm{~m}$; steel truss structure, tilt by small winch

5. Monitoring parameters
Cable length, cable tension, winch speed, power-supply voltage, motor voltage, motor current, motor rotation, cutter rotation, cutter load, drill inclination, hole liquid pressure, temperatures (gear section, drill motor, drill computer, hole liquid, winch, drill-site), alarm signals (anti-torque failer, pressure tight failer) inner barrel to transport chips upward while the barrel is rotating. The chips are forced into a $3.3 \mathrm{~m}$ long chip chamber, located above the core barrel, by a fin-like booster. The motor, reduction gear and computer section are located in a sealed chamber designed to withstand the pressure of a $3500 \mathrm{~m}$ deep fluid-loaded borehole.

The drill transmits 25 operational parameters every second to a computer at the surface. The most important parameters (cable tension, cutter load, drill inclination, etc.) are shown graphically against depth or time to assist drilling and winch operations.

The winch speed can be delicately controlled to speeds as slow as $1 \mathrm{~cm} \mathrm{~min}^{-1}$. For safety and ease of operation, threshold values of depth and cutter load can be set, which if exceeded stop the winch. Alarm signals can also be set to draw the operator's attention to any abnormal operation.

Because of the drill's low energy consumption, a generator of $22.4 \mathrm{~kW}$ has enough capacity to power the total drill system even when the core-processing line (which uses additional power) is active.

\subsection{Drilling operation}

The deep drilling started on 23 August 1995 from the bottom of the pilot hole at a depth of $112 \mathrm{~m}$. The drilling terminated at a depth of $2503.52 \mathrm{~m}$ on 8 December 1996. Drilling was carried out in two shifts with two operators on each shift. Typical hoisting and lowering speeds were 70-80 and $80-90 \mathrm{~cm} \mathrm{~min}^{-1}$, respectively. The average time for cutting a $2 \mathrm{~m}$ core was $20 \mathrm{~min}$. The temperature of the drilling-site was kept in the range $-25^{\circ}$ to $-35^{\circ} \mathrm{C}$, even in the winter when the outside air temperature dropped below $-70^{\circ} \mathrm{C}$, by injecting warm air from the generator hut with a blast tube.

The total number of drilling runs was 1370 , and 836 chip collection runs were made. The average length of core obtained per run was $1.75 \mathrm{~m}$.

Core quality was excellent over the full length of the core, even in the brittle zone between 500 and $840 \mathrm{~m}$ depth. The good core quality is thought to be mainly due to the small cut rate, which was kept as low as $2 \mathrm{~mm} \mathrm{rev}^{-1}$ because of the ice hardness at temperatures of $-50^{\circ}$ to $-60^{\circ} \mathrm{C}$. In the top $1800 \mathrm{~m}$ the borehole was kept almost vertical, with inclinations less than $0.5^{\circ}$. The inclination then increased gradually to $4.6^{\circ}$ at $2250 \mathrm{~m}$ depth. At greater depths, the inclination decreased.

Borehole liquid temperature increased from $-55^{\circ} \mathrm{C}$ at shallow depths to $-20^{\circ} \mathrm{C}$ at $2500 \mathrm{~m}$. Chip collection gradually improved with depth, particularly at depths below

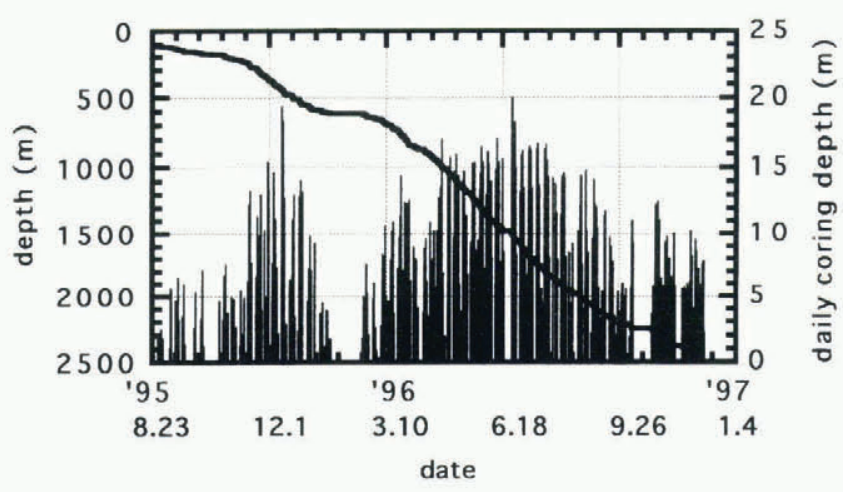

Fig. 4. Drilling progress at Dome Fuji in 1995 and 1996. 


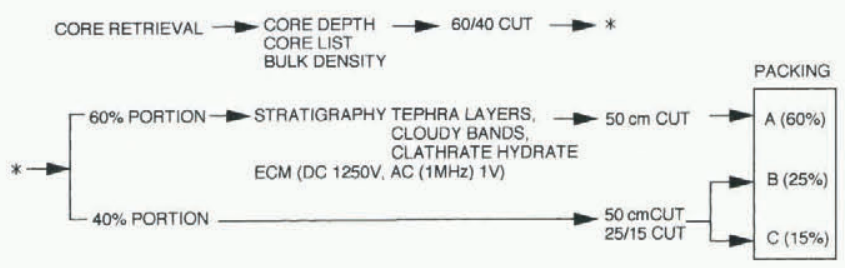

Fig. 5. In situ core-processing procedure at Dome Fuji.

$2000 \mathrm{~m}$, where a larger depth of cut could be used. Nevertheless, we still needed to set aside at least one day a week for chip collection runs. Figure 4 shows the penetration rate and daily coring depth during the drilling in 1995 and 1996.

\section{IN SITU CORE ANALYSIS}

In situ core analysis consisted of electrical conductivity measurements (ECMs), stratigraphical observation and bulk density measurements. ECM included both d.c. measurements (Hammer, 1980) and a.c. measurements (Minikin and Kipfstuhl, 1993; Sugiyama and others, 1995). Stratigraphical observations included careful examination of tephra layers, cloudy bands and air bubbles/clathrate hydrate.

The analysis was carried out in a snow-trench laboratory next to the drilling-site. Drilled cores were stored for 1-4 months before processing and analysis. Figure 5 shows the core-processing procedure carried out at Dome Fuji.

In the processing line, logging and bulk density measurements were made prior to any core-cutting. The cores were then cut in two along the core axis in the ratio $60: 40$. The a.c. and d.c. ECMs and stratigraphical observations were performed on the cut surface of the larger core section. At the end of the core-processing line, the smaller section was further cut in two to give three core pieces as shown in Figure 6. Each of these core pieces was then cut into $50 \mathrm{~cm}$ sections for packing. The analysis-room temperature was normally kept at around $-25^{\circ} \mathrm{C}$ for the ECM. By January 1997, processing had been completed to a depth of $2251 \mathrm{~m}$. Cores from below this depth were processed in the winter of 1997.

\subsection{Density}

Bulk density measurements were obtained by measurement of core length, diameter and weight. The accuracies of $0.5 \mathrm{~cm}, 0.005 \mathrm{~cm}$ and $0.05 \mathrm{~kg}$, respectively, lead to a standard deviation of the density of around $0.5 \%$. The biggest source of error is the irregular shape of the core ends.

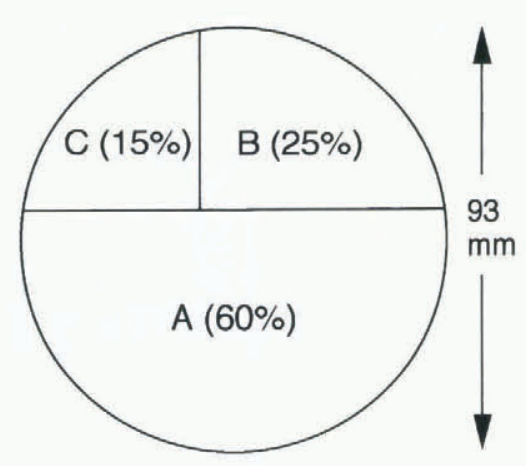

Fig. 6. Core-cutting plan for the Dome Fuji ice core. https://doi.org/10.3189/1998AoG27-1-333-337 Published online by Cambridge University Press

\subsection{EGM}

The d.c. and a.c. ECMs were measured independently in an integrated system. A block diagram of the system is shown in Figure 7. A laptop computer connected to the ECM measuring system via a General Purpose Interface Bus (GPIB) carried out system control and data acquisition. The d.c. and a.c. ECMs used 1250 and $1 \mathrm{~V}$, respectively. The distance between the electrodes was $15 \mathrm{~mm}$ for both d.c. and a.c. ECMs. A potentiometric arrangement is used to determine the position of the electrodes. For the d.c. measurement, the recorded signals were direct current $(\mathrm{A})$ and the electrode position. For the a.c. ECM, the measured signals were admittance (both susceptance and conductance) and the electrode position.

\subsection{Tephra layers}

Continuous stratigraphical observation down to a depth of $2251 \mathrm{~m}$ revealed 25 layers containing visible solid particles. Two layers were found between 500 and $600 \mathrm{~m}$, while the other 23 were found between $1000 \mathrm{~m}$ and $2251 \mathrm{~m}$. The thickness of the layers ranged from 1 to $22 \mathrm{~mm}$. Below $2251 \mathrm{~m}$, the

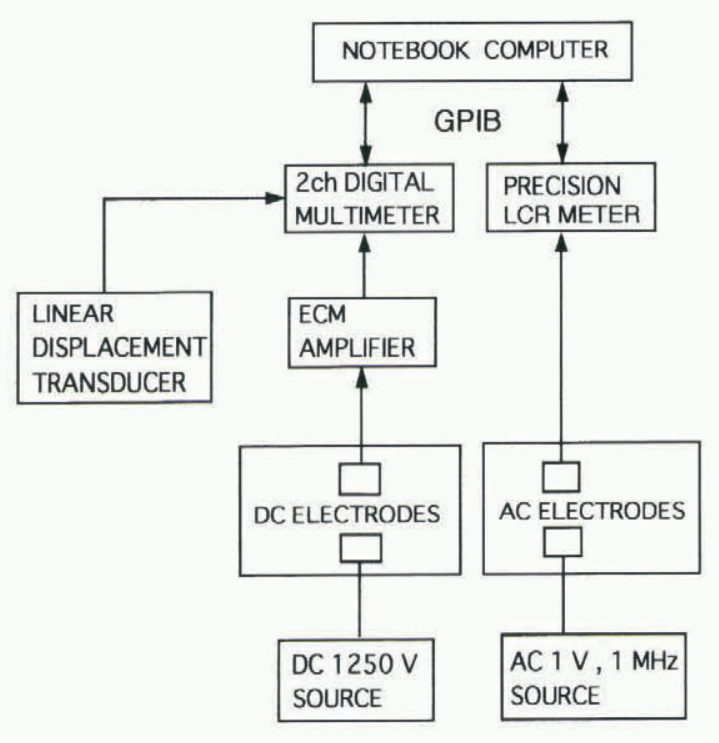

Fig. 7. Block diagram of ECM system.

limit of the continuous stratigraphical observations, a tephra layer was found at $2268 \mathrm{~m}$. The slope of the tephra layers was almost perpendicular to the core axis. The deepest layer has slope of $3^{\circ}$ which coincides with borehole tilt, which suggests that the stratification of the tephra layers is almost horizontal, and no effect of bedrock topography is apparent even at this depth.

\subsection{Brittle zone}

Brittle cores were obtained at depths between about 500 and $840 \mathrm{~m}$. The starting depth of the brittle zone is roughly the same as the depth at which the first cloudy bands and clathrate hydrate crystals appeared. More than 700 distinct cloudy bands were found, as well as many indistinct ambiguous layers. Most of these were found in three depth ranges, around 550,1000 and $2000 \mathrm{~m}$. In contrast, in the other depth ranges cloudy bands were rare. Visible air bubbles were not observed at depths greater than about $1100 \mathrm{~m}$. 


\section{REFERENCES}

Ageta, Y., K. Kamiyama, F. Okuhira and Y. Fujii. 1989. Geomorphological and glaciological aspects around the highest dome in Queen Maud Land, East Antarctica. Proc. NIPR Symp. Polar Meteorol. Glaciol. 2, 88- 96.

Fujii, Y., H. Motoyama and N. Azuma. 1995. Glaciological data collected by the 30th, 31st and 32nd Japanese Antarctic Research Expeditions in 1989-1991. JARE Data Rep. 201.

Fujita, S., T. Yamada, R. Naruse, S. Mae, N. Azuma and Y. Fujii. 1994. Drilling fluid for Dome F project in Antarctica. Natl. Inst. Polar Res. Mem., Special Issue 49, 347-357.

Furukawa, T., K. Kamiyama and H. Maeno. 1996. Snow surface features along the traverse route from the coast to Dome Fuji Station, Queen Maud Land, Antarctica. Proc. NIPR Symp. Polar Meteorol. Glaciol. 10, 13-24.

Hammer, C.U. 1980. Acidity of polar ice cores in relation to absolute dating, past volcanism, and radio-echoes. f. Glaciol., 25 (93), 359-372.

Johnsen, S. J., N. S. Gundestrup, S. B. Hansen, J. Schwander and H. Rufli. 1994. The new improved version of the ISTUK ice core drill. Natl. Inst. Polar Res. Mem., Special Issue 49, 9-23.

Kamiyama, K., T. Furukawa, H. Maeno, T. Kishi and M. Kanao. 1994. Glaciological data collected by the 33rd Japanese Antarctic Research Expedition in 1992. JARE Data Rep. 194.

Maeno, H. and 7 others. 1994. Using a mobile radio echo sounder to measure bedrock topography in east Queen Maud Land, Antarctica. Proc. NIPR Symp. Polar Meteorol. Glaciol. 8, 149-160.

Minikin, A. and J. Kipfstuhl. 1993. Preliminary results of the in situ core processing of the new $320 \mathrm{~m}$ ice core from the central Filchner-Ronne
Ice Shelf: ECM, AC conductivity and density. In Oerter, H., ed. FilchnerRonne Ice Shelf Programme. Report 6. Bremerhaven, Alfred Wegener Institute for Polar and Marine Research, 54-60.

Morgan, V., E. Wehrle, A. Fleming, M. Richardson, A. Elicheikh and R. Brand. 1994. Technical aspects of deep ice drilling on Law Dome. Natl. Inst. Polar Res. Mem., Special Issue 49, 78-86.

Motoyama, H. and 8 others. 1995a. Preliminary study of ice flow observations along traverse routes from coast to Dome Fuji, East Antarctica by differential GPS method. Antart. Rec., 39(2), 94-98.

Motohama, H., H. Enomoto, M. Miyahara and O. Watanabe. 1995b. Shallow ice coring and borehole casing at Dome Fuji Station, East Antarctica. Antart. Rec., 39(2), 189-197.

Naruse, R. 1978. Surface ice flow and strain of the ice sheet measured by a triangulation chain in Mizuho Plateau. Natl. Inst. Polar Res. Mem., Special Issue 7, 198-226.

Nishio, F. and Y. Ageta. 1997. Ice sheet surface. In Antarctica: east Queen Maud Land/Enderby Land glaciological folio. Tokyo, National Institute of Polar Research, Sheet 1.

Nishio, F., S. Mae, H. Ohmae, S. Takahashi, M. Nakawo and K. Kawada. 1989. Dynamical behaviour of the ice sheet in Mizuho Plateau, East Antarctica. Proc. NIPR Symp. Polar Meteorol. Glaciol. 2, 97-104.

Sugiyama, K., S. Fujita, S. Sueoka, S. Mae and T. Hondoh. 1995. Preliminary measurement of high-frequency electrical conductivity of Antarctic ice with AC-ECM technique. Proc. NIPR Symp. Polar Meteorol. Glaciol. 9, $12-22$.

Tanaka, Y. and 6 others. 1994. Development of a JARE deep ice core drill system. Natl. Inst. Polar Res. Mem., Special Issue 49, 113-123. 